\title{
Patent Ductus Arteriosus Increases Lung Fluid Filtration in Preterm Lambs
}

\author{
GAD ALPAN, RICHARD SCHEERER, RICHARD BLAND, AND RONALD CLYMAN \\ Cardiovascular Research Institute and the Department of Pediatrics, University of California, \\ San Francisco, California 94143
}

\begin{abstract}
Previous studies showed that increased pulmonary blood flow from a patent ductus arteriosus had little or no effect on the amount of fluid in the lungs of mechanically ventilated preterm lambs. The purpose of this study was to examine the effect of a patent ductus arteriosus on lung vascular permeability and to see whether increased pulmonary lymph flow might compensate for the increased rate of fluid filtration. Using a model that allows mechanical control of ductus patency, we studied the effects of increased pulmonary blood flow on lung vascular pressures in six mechanically ventilated premature lambs at $136 \pm 2$ d gestation $($ mean $\pm \mathrm{SD})($ term $=145 \mathrm{~d})$. We measured lung lymph flow and protein concentrations in lymph and plasma to assess pulmonary vascular fluid filtration and protein permeability. We studied each lamb during sequential steady state periods, first with the ductus open and then with it closed. When the ductus was open, pulmonary blood flow was twice what it was when the ductus was closed. Mean pulmonary artery pressure and left ventricular end-diastolic pressure were greater with the ductus open $[40 \pm 5$ torr $(5.3 \pm 0.7 \mathrm{kPa})$ and $8 \pm 3$ torr $(1.1 \pm 0.4 \mathrm{kPa})$, respectively] than when it was closed $[24 \pm 3$ torr $(3.2 \pm 0.4 \mathrm{kPa})$ and $4 \pm 2$ torr $(0.5 \pm 0.3$ $\mathrm{kPa}$, respectively]. When the ductus was open, lymph flow was $68 \%$ greater and lymph protein concentration was $17 \%$ lower than when the ductus was closed. Lymph protein clearance (lymph flow $\times$ lymph protein concentration/ plasma protein concentration) was $39 \%$ greater when the ductus was open. Thus, patency of the ductus arteriosus in preterm lambs increases fluid filtration in the pulmonary circulation as a result of increased blood flow and vascular filtration pressure. The resultant increases in lung lymph flow and protein clearance may help to protect the lungs from edema. (Pediatr Res 30: 616-621, 1991)
\end{abstract}

\[ \text { Abbreviations } \]
DA, ductus arteriosus
PDA, patent ductus arteriosus
P $_{\mathrm{LVED}}$, left ventricular end-diastolic pressure
$\overline{\mathbf{P}}_{\mathrm{PA}, \text { mean pulmonary artery pressure }}$
$\mathrm{P}_{\mathrm{c}}$, estimated pulmonary "capillary" pressure
$\mathrm{L:P}$, protein concentration in lymph relative to that in
plasma
$\mathrm{PaO}_{2}$, partial pressure of oxygen in arterial blood
$\mathrm{PaCO}_{2}$, partial pressure of carbon dioxide in arterial blood

Received December 18, 1990; accepted July 23, 1991

Correspondence: Ronald I. Clyman, M.D, Box 0544 HSE 1403, University of California, San Francisco, San Francisco, CA 94143.

Supported in part by grants from the USPHS: Pulmonary SCOR HL 23576 and HL/HD 40802. G.A. was supported by an American Heart Association, California Affiliate, fellowship with funds contributed by the San Mateo County chapter.
The DA is a fetal vascular channel that normally closes soon after birth. If it remains patent, as it often does after premature birth, blood flow from the aorta into the pulmonary artery increases as pulmonary vascular resistance decreases postnatally. A PDA is thus associated with increased pulmonary blood flow, pulmonary blood pressure, and $\mathrm{P}_{\text {LVED }}(1,2)$. The presence of a PDA may cause pulmonary edema in premature infants with respiratory distress $(3,4)$. However, little information is available to demonstrate how the PDA adversely affects pulmonary fluid balance.

Several studies have examined the effects of increased pulmonary blood flow on lung fluid balance in adult and mature newborn animals (5-11). In some of these studies, the increase in microvascular fluid filtration associated with increased pulmonary blood flow was attributed to increased microvascular filtration pressure $(5,6,11)$; in other studies, the increased filtration was thought to be the result of lung vascular recruitment $(7-10)$. There is some evidence that the capacity for vascular recruitment and increased fluid filtration in the pulmonary circulation may be age dependent (10-13). Little information is available regarding the influence of increased perfusion on lung fluid filtration in the presence of underlying pulmonary pathology $(9,14)$, and the relationship between blood flow and fluid dynamics in the immature lung is even more obscure.

We used an animal model of the PDA that enables us to study the effects of increased pulmonary blood flow on lung fluid balance in newborn sheep $(1,2,15)$. Previous studies showed that in premature lambs with respiratory distress during the first $3 \mathrm{~h}$ after operative delivery a $65 \%$ increase in pulmonary blood flow through a PDA had no effect on net water accumulation or albumin transfer from the vasculature into the air spaces (15). We were surprised by these observations and wondered if the capacity of lymphatics to remove liquid and protein from the lungs of preterm lambs might help to prevent development of pulmonary edema associated with a PDA.

We therefore did studies to determine the effects of a PDA on transport of fluid and protein from the pulmonary circulation into the lung interstitium of lambs that were delivered prematurely. We did this by measuring changes in lung lymph flow and lymph protein concentration in the presence and absence of a PDA.

\section{MATERIALS AND METHODS}

Surgical preparation. Surgery was performed on six time-dated pregnant Western mixed-breed ewes at 131-137 d gestation (term $=145 \mathrm{~d}$ ). On the day of surgery, the ewes received $500 \mathrm{mg}$ of ketamine intramuscularly followed by either spinal anesthesia with $1 \%$ tetracaine or general anesthesia with halothane and nitrous oxide delivered with supplemental oxygen through a piston-type mechanical ventilator. When spinal anesthesia was used, the fetus also received intramuscular ketamine to prevent discomfort. The ewe received a continuous i.v. infusion of isotonic saline during surgery. 
Details of the lymph fistula preparation in the fetal lamb have been described previously $(16,17)$. The uterus was opened through a midline abdominal incision, and polyvinyl catheters were threaded through a fetal hind limb artery and vein into the abdominal aorta and vena cava. Through a second uterine incision, a right thoracotomy was performed for placement of a catheter in the outflow duct of the caudal mediastinal lymph node, which in lambs receives one half to two thirds of the total lung lymph (18). The tail of the lymph node was ligated just above the diaphragm to minimize contamination from nonpulmonary sources $(19,20)$, and a polyvinyl catheter with multiple drainage holes was placed in the right pleural space. Because the caliber of the lymph cannula may affect flow through it (21), the heparin-coated lymphatic catheter was constructed to minimize outflow resistance: a $1-$ to $2-\mathrm{cm}$ polyvinyl segment $(0.28 \mathrm{~mm}$ inner diameter, $0.61 \mathrm{~mm}$ outer diameter), which fit snugly within the lymphatic vessel was glued into a large-bore segment $(0.76$ $\mathrm{mm}$ inner diameter, $1.27 \mathrm{~mm}$ outer diameter), the inner diameter of which was larger than that of the lymph vessel itself. After placement of a catheter in the amniotic cavity, both the uterine and abdominal incisions were closed with heavy silk suture. Penicillin and kanamycin were administered into the amniotic cavity and into the fetal vein. Fetal vascular and lymph catheters were tunneled through the uterine and abdominal incisions, and fetal pulmonary lymph was collected in a heparinized container sewn to the ewe's flank. Antibiotics (penicillin and kanamycin) were administered daily to the fetus and into the amniotic cavity. The ewes also received a daily mixture of penicillin and dihydrostreptomycin (Combiotic; Pfizer, New York, NY) with kanamycin.

Two d after the first surgery, we collected lung lymph from four fetuses at 30-min intervals for 1.5-2 $\mathrm{h}$. The height of the external tip of the lymph catheter was kept at the level of the left atrium, which was determined at the time of surgery.

The ewes then underwent a second operation, also with spinal anesthesia supplemented by intermittent i.v. injections of ketamine for sedation. During this surgery, fetal incisions were carried out with s.c. injections of $0.5 \%$ lidocaine. The midline abdominal incision was reopened and the uterus was cut to expose the fetal chest. A left thoracotomy was performed, and the left lung was retracted to expose the pulmonary artery and the DA. After the DA was dissected from the surrounding tissue, $0.2-0.4 \mathrm{~mL}$ of $10 \%$ buffered formalin solution was injected into the vessel wall to destroy the muscular layer. A mechanical snare (made from a cardiac catheterization guide wire and a catheter sheath) was then looped around the DA and brought through the fetal chest wall. A catheter that was placed in the pulmonary artery was tunneled through the thoracotomy incision, after which the fetal chest was closed. A polyvinyl catheter was threaded into the right upper pedal artery. The fetus was then intubated with a $4.5 \mathrm{~F}$ cuffed endotracheal tube. Sheep surfactant, prepared from lung lavages of healthy adult sheep as previously described (22), was instilled into the trachea (50 mg lipid/ $\mathrm{kg}$ body $\mathrm{wt}$ ), and the fetus was maneuvered from side to side to achieve even lung distribution. This treatment enables survival of premature lambs for several hours $(22,23)$. The umbilical cord then was ligated and the lamb was delivered to a warming table, where mechanical ventilation was initiated with a timecycled, constant flow infant ventilator (Sechrist, Anaheim, CA). Under local anesthesia, additional polyvinyl catheters were inserted into another pedal vein, umbilical artery, jugular vein, and carotid artery. The latter two catheters were advanced into the superior vena cava and into the left ventricle, respectively.

Postnatally the lambs were kept in the prone position, and they were paralyzed with $0.4 \mathrm{mg} /$ dose of pancuronium bromide throughout the period of mechanical ventilation. In addition, the lambs received diazepam, $0.15 \mathrm{mg} / \mathrm{kg}$ i.v., for sedation. All intravascular catheters were kept patent during the experiment by infusion of small boluses of heparinized 5\% dextrose in water. The lambs also received an i.v. infusion of $5 \%$ dextrose in water with sodium bicarbonate $(5 \mathrm{mEq} / 50 \mathrm{~mL})$ at an hourly rate of $\sim 5 \mathrm{~mL} / \mathrm{kg}$. The lambs were dried with a towel and covered with a plastic sheet to minimize evaporative heat loss. Rectal temperature was maintained at $38-39^{\circ} \mathrm{C}$ with an Aquamatic K-pad (American Hospital Supply, McGaw Park, IL) and with radiant heat lamps. Heparinized fetal or maternal blood was transfused to replace blood loss. The gestational age of the lambs at the time of study was $136 \pm 2 \mathrm{~d}$ (mean $\pm \mathrm{SD}$ ), and they weighed $3935 \pm 628 \mathrm{~g}$.

Experimental protocol. The experiment began when the umbilical cord was ligated. The ventilator settings were: peak inspiratory pressure $24-25 \mathrm{~cm} \mathrm{H}_{2} \mathrm{O}(2.4 \mathrm{kPa})$, positive end-expiratory pressure $2.5-3 \mathrm{~cm} \mathrm{H}_{2} \mathrm{O}(0.25-0.3 \mathrm{kPa})$, inspiratory time $0.6 \mathrm{~s}$, respirator rate $40 / \mathrm{min}$, and fractional concentration of $\mathrm{O}_{2}$ in inspired gas 1.0. After a brief stabilization period, peak inspiratory pressures and ventilator rates were reduced to maintain the $\mathrm{PaCO}_{2}$ at $\sim 30 \mathrm{~mm} \mathrm{Hg}(3.9 \mathrm{kPa})$. Other ventilator settings remained constant, and when the desired $\mathrm{PaCO}_{2}$ values were attained (usually within $1 \mathrm{~h}$ after birth), no further changes were made. These settings were maintained for two reasons: $l$ ) so that any observed differences in lymph flow could not be attributed to differences in mode of ventilation, and 2) to prevent respiratory acidosis or hypoxia, which could confound the interpretation of our results.

The distal tip of the lymph catheter was maintained at a constant height at the level of the left atrium. Lymph was collected continuously in heparin-coated test tubes; samples were taken every $30 \mathrm{~min}$, and volume was measured to the nearest $0.01 \mathrm{~mL}$. The samples were spun in a microfuge for $5 \mathrm{~min}$ to obtain supernatant fluid for protein measurements. Blood samples were drawn every hour for measurement of arterial $\mathrm{pH}$, $\mathrm{PaCO}_{2}, \mathrm{PaO}_{2}$, and hematocrit. Blood gases were measured with a Corning blood gas analyzer (Corning Medical and Scientific, Medfield, MA) with appropriate corrections for the prevailing body temperature. Hourly blood samples were centrifuged for measurement of plasma protein concentration. Vascular and left ventricular pressures were measured continuously with a Sensormedic Dynograph R611 multichannel recorder connected to Beckman pressure transducers (Sensormedic, Anaheim, CA). Signals were averaged electronically to obtain mean pressures.

During the initial phase of the experiment, the DA remained open. After lymph flow reached a steady state, left ventricular output, pulmonary blood flow, and flow through the DA were determined by injection of radiolabeled microspheres. Steady state lymph flow was defined as four consecutive 30-min periods of lymph collection in which the volumes of lymph had a coefficient of variation of less than $10 \%$. At the end of this $2-h$ period, two different radiolabeled microspheres $\left({ }^{51} \mathrm{Cr}\right.$ and $\left.{ }^{114} \mathrm{In}\right)$ were injected into the left ventricle and the inferior vena cava while reference blood samples were continuously withdrawn from the ascending and descending aorta $(15,24)$.

After this, the DA was mechanically closed by tightening the snare. After a 2-h period of steady state lymph flow (as defined above) during which the DA was closed, another microsphere flow study was carried out using two different radiolabeled microspheres $\left({ }^{57} \mathrm{Co}\right.$ and $\left.{ }^{65} \mathrm{Zn}\right)$. In four animals the experiment ended at this point. In two lambs, we were able to open the DA again, and when a steady state was achieved for $2 \mathrm{~h}$, we performed another microsphere flow study (using ${ }^{95} \mathrm{Nb}$ and ${ }^{113} \mathrm{Sn}$ ). In one of these animals, the DA was then closed a second time, and after a 2-h period of steady state lymph flow, an additional microsphere flow study was performed (using ${ }^{153} \mathrm{Gd}$ and ${ }^{85} \mathrm{Sr}$ ).

At the end of the experiments, the animals were killed with 50 $\mathrm{mg} / \mathrm{kg}$ pentobarbital, their chests were opened, their lungs were examined, and the catheter positions were identified.

Cardiovascular function measurements. At the end of the experiment, the organs and carcass were separated, placed in formalin, incinerated at $325^{\circ} \mathrm{C}$ for $72 \mathrm{~h}$, pulverized, and placed in counting vials. The amount of radionuclide in each organ and reference blood sample was measured with a well-type gamma- 
scintillation counter and a multiple-channel pulse analyzer $(22$, 24-26). Left ventricular output, pulmonary blood flow, blood flow through the DA, and the right to left foramen ovale shunt were calculated from the concentration of microspheres in the reference samples, the total number of microspheres recovered from the whole animal, and the total number of microspheres in the lungs $(22,24-26)$. Bronchial blood flow was assumed to be $8 \%$ of the measured left ventricular output; this assumption was based on measurements made in 35 premature newborn lambs with ligated ductus (Clyman RI, unpublished observations). Pulmonary blood flow was assumed to equal left ventricular output minus estimated bronchial blood flow and the right to left shunt measured through the foramen ovale (26).

Pulmonary vascular resistance was calculated as: $\left(\overline{\mathrm{P}}_{\mathrm{PA}}-\right.$ $\left.\mathrm{P}_{\mathrm{LVED}}\right)$ /pulmonary blood flow. $\mathrm{P}_{\mathrm{c}}$ was calculated using Gaar's equation (5) in the form $\mathrm{P}_{c}=\mathrm{P}_{\mathrm{LVED}}+0.4\left(\overline{\mathrm{P}}_{\mathrm{PA}}-\mathrm{P}_{\mathrm{LVED}}\right)$. This equation correlates well with capillary pressure as measured by arterial occlusion (5) and has been used in experiments with pulmonary overperfusion (6). Although the assumptions underlying the partition values chosen in this equation may not hold in conditions of very high pulmonary flow, we are using $P_{c}$ as an index of filtration pressure. There is evidence that this index is a reasonable measure whatever the value of pulmonary flow; even when the arteriovenous pressure difference is large, $P_{c}$ may remain the average midpoint filtration pressure over a wide range of vascular pressures (5). The partition of vascular resistance implied in Gaar's equation conforms with recent studies on the segmental distribution of pulmonary vascular resistance in young lambs. Using micropuncture techniques in isolated perfused lamb lungs, Raj and Chen $(27,28)$ found that arteries, microvessels, and veins contribute approximately one third each to the pulmonary vascular resistance. Thus, the calculated $P_{c}$ is close to the midrange of the microvascular pressure measured by Raj and Chen.

Biochemical assays. Samples of lymph and blood were centrifuged and protein concentrations of the supernatant liquids were measured by the biuret method (29). Cellulose acetate electrophoresis (Microzone 110; Beckman Instruments, Inc., Fullerton, CA) was used to determine concentrations of albumin and globulin in lymph and plasma.

Statistical analysis. We used a paired $t$ test to compare measurements obtained with the DA open versus measurements obtained with the DA closed. In the two animals that we studied more than once with the DA open, only the first periods of DA patency and closure were used for statistical analysis (i.e. the first two states that were sequentially equivalent to the studies in the other four animals). Values of $p<0.05$ were considered significant. Results are presented as mean \pm SD.

\section{RESULTS}

Cardiovascular and respiratory variables. Throughout the experiment there was little variability in ventilatory settings of arterial blood gas values (Table 1). $\mathrm{PaO}_{2}$ was slightly higher when the DA was patent; this finding has been described previously $(1,2)$ and probably results from pulmonary recirculation of oxygenated blood through a left to right ductal shunt and decreased right to left shunt through the foramen ovale.

Cardiovascular data are summarized in Table 2. The left to right shunt through the DA averaged $61 \%$ (range $40-71 \%$ ); this was equivalent to a pulmonary:systemic flow ratio of $2.4: 1$. When the DA was open, $\overline{\mathrm{P}}_{\mathrm{PA}}$ and $\mathrm{P}_{\text {LVED }}$ were higher than they were when the DA was closed; mean systemic blood pressure was lower when the DA was open than it was when the DA was closed. When the DA was open, left ventricular output was $70 \%$ higher and pulmonary blood flow was almost twice what it was when the DA was closed. In addition, pulmonary vascular resistance and systemic blood flow were significantly less when the DA was open than when it was closed.

Lung lymph data. In four lambs we measured steady state lung
Table 1. Respiratory data in six lambs with a PDA*

\begin{tabular}{llcc}
\hline & & Ductus open & Ductus closed \\
\hline PIP/PEEP & $\left(\mathrm{cm} \mathrm{H} \mathrm{H}_{2} \mathrm{O}\right)$ & $22 \pm 2 / 3 \pm 0.4$ & $22 \pm 2 / 3 \pm 0.4$ \\
& $(\mathrm{kPa})$ & $2.2 \pm 0.2 / 0.3 \pm 0.0$ & $2.2 \pm 0.2 / 0.3 \pm 0.0$ \\
$\mathrm{IMV}$ rate & $\left(\mathrm{min}^{-1}\right)$ & $34 \pm 4$ & $34 \pm 4$ \\
$\mathrm{pH}$ & & $7.47 \pm 0.07$ & $7.52 \pm 0.07$ \\
$\mathrm{PaO}_{2}$ & $(\mathrm{~mm} \mathrm{Hg})$ & $480 \pm 66$ & $336 \pm 103 \dagger$ \\
& $(\mathrm{kPa})$ & $64 \pm 9$ & $45 \pm 14 \dagger$ \\
$\mathrm{PaCO}_{2}$ & $(\mathrm{~mm} \mathrm{Hg})$ & $30 \pm 5$ & $28 \pm 3$ \\
& $(\mathrm{kPa})$ & $4 \pm 1$ & $4 \pm 0.2$ \\
\hline
\end{tabular}

$*$ Values represent mean \pm SD. PIP, peak-inspiratory pressure; PEEP positive end-expiratory pressure; IMV, intermittent mandatory ventilation.

$\dagger$ Significant difference between values for ductus open and ductus closed, $p<0.05$.

Table 2. Hemodynamic data in six lambs with a PDA*

\begin{tabular}{llcc}
\hline & & Ductus open & Ductus closed \\
\hline$\overline{\mathrm{P}}_{\mathrm{A}}$ & $(\mathrm{mm} \mathrm{Hg})$ & $50 \pm 9$ & $57 \pm 7$ \\
& $(\mathrm{kPa})$ & $6.7 \pm 1.2$ & $7.6 \pm 0.9$ \\
$\overline{\mathrm{P}}_{\mathrm{PA}}$ & $(\mathrm{mm} \mathrm{Hg})$ & $40 \pm 5$ & $24 \pm 3$ \\
& $(\mathrm{kPa})$ & $5.3 \pm 0.6$ & $3.2 \pm 0.4$ \\
$\mathrm{P}_{\mathrm{LVED}}$ & $(\mathrm{mm} \mathrm{Hg})$ & $8 \pm 3$ & $4 \pm 2$ \\
& $(\mathrm{kPa})$ & $1.1 \pm 0.4$ & $0.6 \pm 0.3$ \\
$\overline{\mathrm{P}}_{\mathrm{IVC}}$ & $(\mathrm{mm} \mathrm{Hg})$ & $2 \pm 2$ & $2 \pm 2$ \\
& $(\mathrm{kPa})$ & $0.2 \pm 0.3$ & $0.2 \pm 0.2$ \\
$\mathrm{P}_{\mathrm{c}}$ & $(\mathrm{mm} \mathrm{Hg})$ & $21 \pm 2$ & $12 \pm 2$ \\
& $(\mathrm{kPa})$ & $2.8 \pm 0.3$ & $1.6 \pm 0.3$ \\
$\mathrm{Hct}_{\mathrm{c}}$ & $(\%)$ & $42 \pm 2$ & $41 \pm 2$ \\
$\dot{\mathrm{Q}}_{\mathrm{LV}}$ & $(\mathrm{mL} / \mathrm{kg} / \mathrm{min})$ & $318 \pm 69$ & $187 \pm 20$ \\
$\dot{\mathrm{Q}}_{\mathrm{P}}$ & $(\mathrm{mL} / \mathrm{kg} / \mathrm{min})$ & $291 \pm 64$ & $147 \pm 9$ \\
$\mathrm{PVR}$ & $(\mathrm{mm} \mathrm{Hg} / \mathrm{L} / \mathrm{kg} / \mathrm{min})$ & $109 \pm 12$ & $134 \pm 23$ \\
& $(\mathrm{kPa} / \mathrm{L} / \mathrm{kg} / \mathrm{min})$ & $15 \pm 2$ & $18 \pm 3$ \\
$\dot{\mathrm{Q}}_{\mathrm{s}}$ & $(\mathrm{mL} / \mathrm{kg} / \mathrm{min})$ & $121 \pm 28$ & $187 \pm 24$ \\
$\mathrm{PDA} \mathrm{L} \rightarrow \mathrm{R}$ shunt & $(\%$ of Q Q & $61 \pm 11$ & $0 \pm 4$ \\
\hline
\end{tabular}

* Values represent mean $\pm \mathrm{SD}$. $\overline{\mathrm{P}}_{\mathrm{A}}$, mean systemic blood pressure; $\overline{\mathrm{P}}_{\mathrm{IVC}}$, mean inferior vena cava pressure; $\dot{\mathrm{Q}}_{\mathrm{Lv}}$, left ventricular output; $\dot{\mathrm{Q}}_{\mathrm{p}}$, pulmonary blood flow; PVR, pulmonary vascular resistance; $\dot{Q}_{s}$, systemic blood flow; Hct, hematocrit; and $\mathrm{L} \rightarrow \mathrm{R}$, left to right. Differences were statistically significant for all variables except $\overline{\mathrm{P}}_{\mathrm{IVC}}$ and Hct, $p<0.05$.

lymph flow before delivery: lymph flow averaged $2.3 \pm 0.5 \mathrm{~mL} /$ $h$ in these lambs; $L: P$ averaged $0.73 \pm 0.03$ for these four studies. Lymph protein concentration in fetal lambs was $2.57 \pm 0.14 \mathrm{~g} /$ $100 \mathrm{~mL}$, and lymph protein clearance (lymph flow $\times \mathrm{L}: \mathrm{P}$ ) was $1.7 \pm 0.3 \mathrm{~mL} / \mathrm{h}$.

Figure 1 illustrates the time course of one study in which we measured lymph flow and vascular pressures during two periods in which the DA was open and two periods in which it was closed. After delivery, lymph flow increased and L:P decreased compared with fetal values. By 2-3 h after delivery, these changes reached their respective peak and nadir. The initial changes probably occurred as a result of absorption of protein-free liquid from the lung lumen into the interstitium after delivery (16). Lymph flow then decreased and lymph protein concentration increased until a steady state was achieved $7-8 \mathrm{~h}$ after delivery. Postnatal lymph flow with the DA open was higher than lymph flow before birth, and L:P was less after birth than it was before birth.

During the steady state period in which the DA was closed, pulmonary blood flow, $\overline{\mathrm{P}}_{\mathrm{PA}}$, and $\mathrm{P}_{\mathrm{LVED}}$ were less than they were when the DA was open. Lymph flow was less and L:P was greater when the DA was closed. Reopening the DA caused increases in pulmonary blood flow, $\overline{\mathrm{P}}_{\mathrm{PA}}, \mathrm{P}_{\mathrm{LVED}}$, and lung lymph flow; L:P decreased. A steady state was achieved within $1 \mathrm{~h}$ after reopening the DA. We then closed the DA a second time. There was an immediate decrease in $\overline{\mathrm{P}}_{\mathrm{PA}} \mathrm{P}_{\mathrm{LVED}}$, and a new steady state occurred 


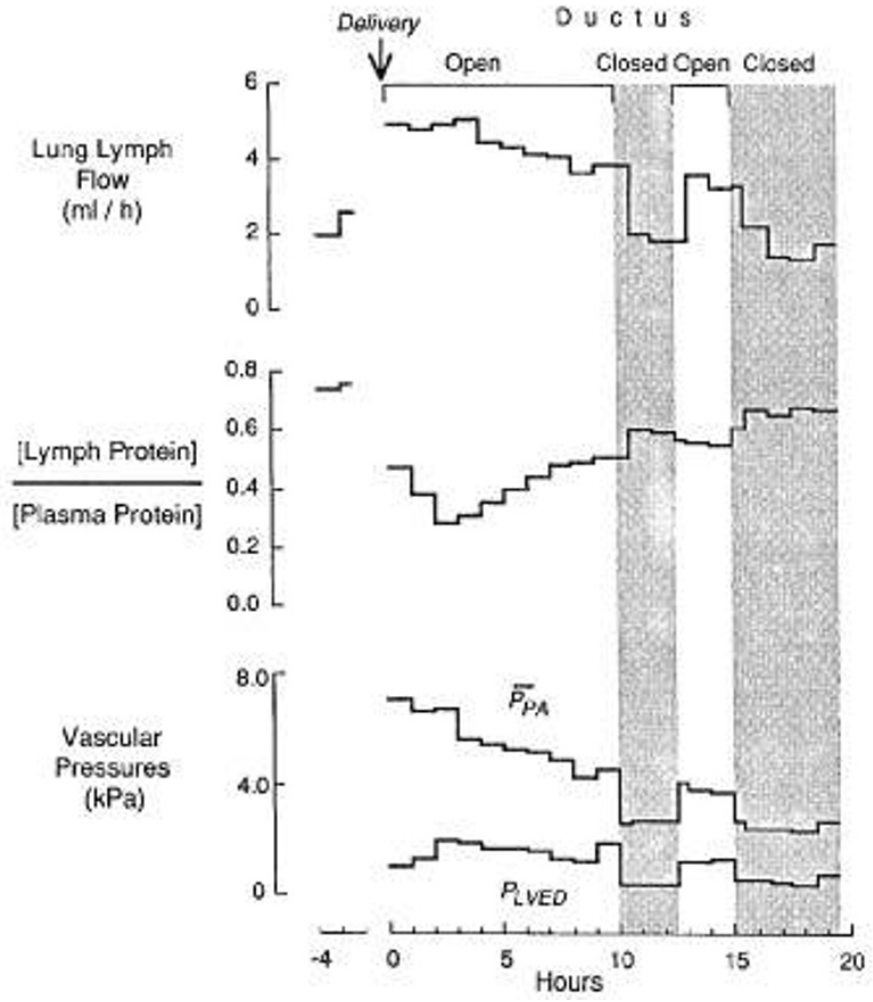

Fig. 1. Time course of one experiment in a lamb that had its open DA closed two times. Lung blood flow decreased by $40 \%$ when the DA was closed the first time, and it decreased by $\sim 50 \%$ when the DA was closed the second time.

Table 3. Lymph data in six lambs with a PDA*

\begin{tabular}{lcc} 
& Ductus open & Ductus closed \\
\hline$\dot{\mathrm{Q}}_{\mathrm{L}}(\mathrm{mL} / \mathrm{h})$ & $3.4 \pm 0.8$ & $2.0 \pm 0.6 \dagger$ \\
$\mathrm{L}_{\mathrm{P}}(\mathrm{g} / 100 \mathrm{~mL})$ & $1.90 \pm 0.29$ & $2.29 \pm 0.36 \dagger$ \\
$\mathrm{P}_{\mathrm{P}}(\mathrm{g} / 100 \mathrm{~mL})$ & $3.17 \pm 0.23$ & $3.19 \pm 0.28$ \\
$\mathrm{~L}: \mathrm{P}$ & $0.60 \pm 0.07$ & $0.72 \pm 0.07 \dagger$ \\
$\mathrm{Q}_{\mathrm{L}} \times \mathrm{L}: \mathrm{P}(\mathrm{mL} / \mathrm{h})$ & $2.0 \pm 0.4$ & $1.4 \pm 0.5 \dagger$ \\
$\%$ Albumin & & \\
Lymph & $64 \pm 5$ & $63 \pm 6$ \\
Plasma & $56 \pm 4$ & $55 \pm 4$ \\
\hline
\end{tabular}

* Values represent mean $\pm \mathrm{SD}$. $\dot{\mathrm{Q}}_{\mathrm{L}}$, lymph flow; $\mathrm{L}_{\mathrm{P}}$, lymph protein concentration; $\mathrm{P}_{\mathrm{P}}$, plasma protein concentration; $\mathrm{Q}_{\mathrm{L}} \times \mathrm{L}: \mathrm{P}$, lymph protein clearance; and \% Albumin, albumin concentration as a percentage of total protein concentration.

$\dagger$ Significant difference between values for ductus open and ductus closed, $p<0.05$.

within 60 min of closure of the DA. Lymph flow decreased and L:P increased.

The results for all six lambs, summarized in Table 3, pertain only to the first period of DA patency and the first period of DA closure after delivery. These results follow the pattern illustrated by the individual lamb in Figure 1. When the DA was open, $\overline{\mathrm{P}}_{\mathrm{PA}}$ and $\mathrm{P}_{\mathrm{LVED}}$ were significantly higher than they were when the DA was closed; pulmonary blood flow was twice what it was when the DA was closed. Lymph flow was 70\% greater and L:P was $17 \%$ less when the DA was open than when it was closed. Lymph protein clearance was $40 \%$ greater when the DA was open. All of these differences were statistically significant. The ratio of albumin:globulin in lymph and plasma was unaffected by the presence or absence of a PDA, indicating that increased blood flow through the DA did not affect protein sieving in the pulmonary microcirculation.

\section{DISCUSSION}

This study examined the effects of a PDA on pulmonary hemodynamic and lung lymph variables in mechanically ventilated, surfactant-treated, premature lambs. Preterm lambs studied during the first $3 \mathrm{~h}$ of life at $135 \mathrm{~d}$ gestation have a 4-fold increase in the rate of albumin entry into the lung air spaces compared with full-term animals (30). Because the DA is open in premature lambs in the first few hours after birth $(31,32)$, the permeability changes might have been due to the hemodynamic effects of a PDA. In a previous study (15), we assessed the effects of DA patency on the amount of liquid in the lungs of mechanically ventilated, surfactant-treated, premature lambs $3 \mathrm{~h}$ after delivery. In that study, neither net water accumulation nor net albumin entry into the air spaces were different. When animals with an open DA were compared with those with a closed DA, however, the fraction of albumin contained in lung tissue was greater in the animals with an open DA (67 versus $50 \%$ with the DA closed).

Under steady state conditions, lung lymph flow reflects net filtration of liquid from the pulmonary circulation into the interstitium, and the protein concentration of lung lymph approximates that of lung interstitial liquid (33). Our results indicate that a PDA is associated with increased lymph flow rates and protein clearance in premature lambs. An open DA caused pulmonary blood flow to double; $\overline{\mathrm{P}}_{\mathrm{PA}}$ and $\mathrm{P}_{\mathrm{LVED}}$ increased by 16 $\mathrm{mm} \mathrm{Hg}(2.1 \mathrm{kPa}, 66 \%$ change) and $4 \mathrm{~mm} \mathrm{Hg}(0.5 \mathrm{kPa}, 98 \%$ change), respectively, compared with values obtained when the DA was closed. Lymph flow was $68 \%$ greater, L:P was $17 \%$ less, and lymph protein clearance was $39 \%$ greater when the DA was open than when it was closed.

The sequence of DA patency and closure was identical in all six experiments (with the DA initially open). For several reasons, however, we do not think that the observed changes were simply a function of time after birth. First, the changes in vascular pressures and lymph flow occurred abruptly (within $30 \mathrm{~min}$ ) after DA closure. Second, the interval between birth and DA closure varied from 5 to $11 \mathrm{~h}$ in these experiments, but the temporal sequence of changes in lymph flow consistently matched the time of DA closure. Moreover, in the two lambs in which the DA was opened a second time, the second opening of the DA was associated with an increase in lymph flow and a decrease in L:P. In the one animal in which the DA was closed a second time, lymph flow and protein concentration decreased and increased, respectively, to values similar to those observed in this animal during its first period of DA closure (Fig. 1).

We also do not think that differences in respiratory gas exchange or ventilatory variables can explain the observed differences in lymph flow and L:P. Arterial pH and $\mathrm{PaCO}_{2}$ were stable throughout each experiment, and although there were differences in $\mathrm{PaO}_{2}$ with the DA open and closed, neither condition was associated with hypoxia, which may increase lung lymph flow in newborn lambs (34). Thus, differences in oxygenation that occurred in these experiments should not have affected lymph flow. Ventilatory settings were similar with the DA open and closed, so that patterns of ventilation should not have affected lymph flow appreciably. Changes in lymph flow and lymph protein concentration coincided specifically with hemodynamic changes associated with DA patency and closure.

Several conditions may have influenced the absolute values of lymph flow and protein concentration in our lambs. Our animals were studied a few hours after thoracic surgery, which sometimes affects lung lymph flow and lymph protein concentration, although this is not a consistent finding (35). Premature lambs are likely to have immature lungs with respiratory distress $(17,22$, 23,30 ), which also increases lung lymph flow and protein leak $(17,30)$. Although surfactant administration ameliorates this condition $(22,23)$ and reduces the extent of protein leakage in immature lungs (31), its effects are not completely corrective.

There are three major ways by which patency of the DA may 
affect lung lymph flow and protein concentration: by influencing pulmonary microvascular pressure; by altering patency of the lung vascular bed, which in turn may affect microvascular surface area; or by disrupting the normal barrier function of the pulmonary vascular endothelium. Postnatal clearance of liquid from the lung lumen also may affect pulmonary lymph flow and protein concentration during the initial hours after delivery (16, 17).

To examine how the PDA affected pulmonary microvascular fluid filtration, we studied the relationship between lung lymph flow and L:P (Fig. 2), which is a useful way to distinguish between changes in fluid filtration caused by differences in vascular pressure, surface area, or protein permeability. In our preterm lambs with and without a PDA, there was an inverse relationship between lymph flow and L:P. As lymph flow increased in the presence of an open DA, L:P decreased. These results parallel those of previous studies in which lung microvascular pressure was increased in mature newborn lambs by inflating a balloon in their left atrium, with a resultant increase in lung lymph flow and reduction in L:P (36). Data from our experiments show that with an open DA there was $7.8 \%$ increase in lymph flow for each $1 \mathrm{~mm} \mathrm{Hg}$ increase in $\mathrm{P}_{c}$. This is very close to the value of $7.6 \%$ increase in lymph flow $/ \mathrm{mm} \mathrm{Hg}$ change in $\mathrm{P}_{c}$ obtained in the experiments with left atrial hypertension in newborn lambs (36). The similarity of these results suggests that a PDA increases vascular fluid filtration by increasing hydrostatic pressure in the pulmonary microcirculation.

Feltes and Hansen (11) recently reported that increased pulmonary blood flow produced by a conduit between the aorta and pulmonary artery of young lambs increased lymph flow as a result of increased filtration pressure. Our experiments extend their findings by examining the effects of a greater increase in pulmonary blood flow in the preterm lung.

Both pulmonary artery pressure and left atrial pressure influence microvascular filtration pressure in the lungs, and the relative importance of $\overline{\mathrm{P}}_{\mathrm{PA}}$ becomes accentuated under conditions in which pulmonary blood flow is high (37). As pulmonary blood flow increases, the fraction of pulmonary vascular resistance downstream from the effective filtration site increases progressively and may reach $>80 \%$ of total pulmonary vascular resistance at very high flow rates (37). When flow is fast, the effective pressure at the site of fluid filtration within the pulmonary circulation more likely reflects the pressure in the pulmonary artery than it does the pressure in the left atrium. When pulmonary blood flow is extremely high $(>$ three times normal flow), left atrial pressure may contribute relatively little to net filtration pressure (37). This may help to explain why pulmonary edema often exists in preterm infants with a PDA despite a normal left atrial pressure (38).

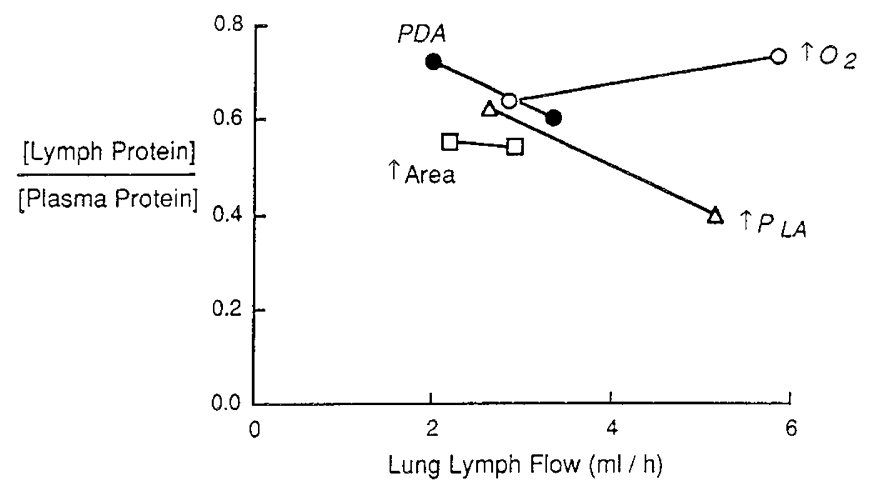

Fig. 2. Index of lung vascular permeability: the relationship between $\mathrm{L}: \mathrm{P}$ and lung lymph flow. Our data (PDA) are compared with data from other experiments: data for increased left atrial pressure are from reference 36; data for pulmonary oxygen toxicity are from reference 43 ; and data for increased blood flow without increased pressure are from reference 10.
The second way that a PDA might increase microvascular fluid filtration is by increasing patency of the pulmonary vascular bed, often described as "vascular recruitment." The fact that pulmonary vascular resistance decreased in our lambs when the DA was open is consistent with this possibility. In a previous study done with lambs that were 2 wk old, a $20 \%$ increase in pulmonary blood flow, which was induced by opening a peripheral arteriovenous fistula, led to a $40 \%$ increase in lung lymph flow without a significant change in lymph protein concentration (Fig. 2). This observation is consistent with an increase in perfused surface area. In the same study, however, when left atrial pressure was increased by $\sim 11 \mathrm{~mm}$ hg $(1.5 \mathrm{kPa})$, increased perfusion had no significant effect on lymph flow. This finding indicates that the vascular bed of the newborn lung has only a modest capacity for recruitment. Blood flow models derived from morphometric data also suggest minimal potential for recruitment of unfilled capillaries at increased rates of blood flow (39). Pitt et al. $(12,13)$ studied healthy lambs that were $1 \mathrm{~d}$ old and found evidence that the newborn lung is already maximally recruited under baseline conditions. When newborn lambs were subjected to hypoxia, however, there was loss of functional vascular surface area, indicating that the newborn lung is capable of "derecruitment" (12). Whether premature lambs, with areas of microatelectasis in their lungs, can open up pulmonary vessels from these "derecruited" zones is unknown. Berry et al. (40) showed that the distribution of blood flow to the lungs may change in premature lambs with artificially induced atelectasis, so that their ventilation:perfusion ratio improves. This finding suggests that vascular tone and vessel caliber in lungs of preterm lambs can change in response to different conditions. In our study, we observed a significant decrease in L:P when lymph flow increased, a result that is not indicative of vascular recruitment.

Our data for lung lymph flow and lymph protein concentration in preterm lambs with and without a PDA also is not consistent with a change in pulmonary vascular permeability. If an open DA had been associated with increased protein permeability, then we would have expected to see little, if any, decrease in L:P as lymph flow increased $(41,42)$. Figure 2 compares our results with those obtained in young lambs with increased lung vascular protein permeability from prolonged oxygen breathing (43). In contrast to our results with preterm lambs and a PDA, L:P increased as lymph flow increased in lambs with pulmonary oxygen toxicity. In studies performed with adult sheep that had almost two thirds of their total lung mass resected, Landolt et al. (6) did not detect any evidence of increased lung vascular permeability, despite the fact that the entire cardiac output of these sheep flowed through only a small fraction of the pulmonary vascular bed. Thus, we think that increased blood flow to the lungs through a PDA, even in relatively small lungs of preterm lambs, does not cause an increase in pulmonary vascular protein permeability.

In summary, this study shows that patency of the DA in preterm lambs is associated with increased lymph flow and protein clearance. The reduction in lymph protein concentration that accompanied the increase in lymph flow indicates that these changes were the result of increased microvascular filtration pressure. Our previous study (15) showed that the lungs of mechanically ventilated premature lambs do not accumulate excess water or protein during the early period after delivery. We infer from our current findings that the increase in lymph flow that occurs when the DA is open probably compensates for the early increase in fluid filtration and protein extravasation that are associated with increased blood flow. Taylor (44) has referred to this compensatory increase in lung lymph flow as an "edema safety factor," which inhibits fluid accumulation in the lungs. We think that this may be an important mechanism for preventing pulmonary edema under conditions of increased fluid filtration, as in preterm lambs with a PDA. If lung lymphatic drainage is impaired, as it may be in the presence of pulmonary 
interstitial emphysema or fibrosis, the likelihood of edema would increase. Furthermore, our studies have not addressed the possibility that prolonged patency of the DA may have an adverse effect on lung fluid balance several days after birth, when pulmonary vascular resistance is much lower than it is during the immediate postnatal period.

Acknowledgments. The authors thank Paul Sagan for his skillful editorial assistance and Diane Lindsay, Françoise Mauray, Carl McWatters, and Bruce Payne for their technical assistance.

\section{REFERENCES}

. Clyman RI, Mauray F, Heymann MA, Roman C 1987 Cardiovascular effects of a patent ductus arteriovenous in preterm lambs with respiratory distress. J Pediatr 111:579-587

2. Pérez Fontán JJ, Clyman RI, Mauray F, Heymann MA, Roman C 1987 Respiratory effects of a patent ductus arteriosus in premature newborn lambs. J Appl Physiol 53:2315-2324

3. Cotton RB, Stahlman MT, Kover I, Catterton W-Z 1978 Medical managemen of small preterm infants with symptomatic patent ductus arteriosus. J Pediatr 92:467-473

4. Stevenson JG 1977 Fluid administration in the association of patent ductus arteriosus complicating respiratory distress syndrome. J Pediatr 90:257-261

5. Grimbert FA, Martin D, Parker JC, Taylor AE 1988 Lymph flow during increases in pulmonary blood flow and microvascular pressure in dogs. Am J Physiol 255:H1149-H1155

6. Landolt CC, Matthay MA, Albertine KH, Roos PJ, Wiener-Kronish JP, Staub NC 1983 Overperfusion, hypoxia, and increased pressure cause only hydrostatic pulmonary edema in anesthetized sheep. Circ Res 52:335-341

7. Coates G, O'Brodovich H, Jefferies AL, Gray GW 1984 Effects of exercise on lung lymph flow in sheep and goats during normoxia and hypoxia. $\mathrm{J}$ Clin Invest 74:133-141

8. O'Brodovich H, Coates G 1986 Effect of isoproterenol or exercise on pulmonary lymph flow and hemodynamics. J Appl Physiol 60:38-44

9. O'Brodovich H, Coates G 1986 Effect of exercise on lung lymph flow in unanesthetized sheep with increased pulmonary vascular permeability. Am Rev Respir Dis 134:862-866

10. Teague WG, Berner ME, Bland RD 1988 Effect of pulmonary perfusion on lung fluid filtration in young lambs. Am J Physiol 255:H1336-H134

11. Feltes TF, Hansen TN 1989 Effects of an aorticopulmonary shunt on lung fluid balance in the young lamb. Pediatr Res 26:94-97

12. Pitt BR, Lister G 1984 Kinetics of pulmonary angiotensin-converting enzyme activity in conscious developing lambs. J Appl Physiol 57:1158-1166

13. Pitt BR, Lister G, Davies P, Reid L 1987 Correlation of pulmonary ACE activity and capillary surface area during postnatal development. J Appl Physiol 62:2031-2041

14. Foy T, Marion J, Brigham KL, Harris TR 1979 Isoproterenol and aminophylline reduce lung capillary filtration during high permeability. $J$ Appl Physiol 46:146-151

15. Alpan G, Mauray F, Clyman RI 1989 Effect of patent ductus arteriosus on water accumulation and protein permeability in the premature lungs of mechanically ventilated premature lambs. Pediatr Res 26:570-575

16. Bland RD, Hansen TN, Haberkern CN, Bressack MA, Hazinski TA, Raj JU, Goldberg RB 1982 Lung fluid balance in lambs before and after birth. J Appl Physiol 53:992-1004

17. Bland RD, Carlton DP, Scheerer RG, Cummings JJ, Chapman DL 1989 Lung fluid balance in lambs before and after premature birth. $J$ Clin Invest 84:568576

18. Humphreys PW, Normand ICS, Reynolds EOR, Strang LB 1967 Pulmonary lymph flow and the uptake of liquid from the lungs of the lamb at the start of breathing. J Physiol (Lond) 193:1-29

19. Chanana AD, Joel DD 1986 Contamination of lung lymph following standard and modified procedures in sheep. J Appl Physiol 60:809-816
20. Drake RR, Laine GA, Allen SJ, Katz J, Gabel JC 1986 Overestimation of sheep lung lymph contamination. J Appl Physiol 61:1590-1592

21. Drake R, Giesler M, Laine G, Gabel J, Hansen T 1985 Effect of outflow pressure on lung lymph flow in unanesthetized sheep. J Appl Physiol 58:7076

22. Clyman RI, Jobe A, Heymann MA, Ikegami M, Roman C, Payne B, Mauray F 1982 Increased shunt through the patent ductus arteriosus after surfactant replacement therapy. J Pediatr 100:101-107

23. Durand DJ, Clyman RI, Heymann MA, Clements JA, Mauray F, Kitterman J, Ballard P 1985 Effects of a protein-free synthetic surfactant on the surviva and pulmonary function of preterm lambs. J Pediatr 107:775-780

24. Heymann MA, Payne BD, Hoffman JIE, Rudolph AM 1977 Blood flow measurements with radionuclide-labeled particles. Prog Cardiovasc Dis 20:55-79

25. Baer RW, Payne BA, Verrier ED, Vlahakes GJ, Molodowitch D, Uhlig PN, Hoffman JIE 1984 Increased number of myocardial blood flow measure ments with radionuclide-labeled microspheres. Am J Physiol 246:H418 $\mathrm{H} 434$

26. Teitel D, Iwamoto HS, Rudolph AM 1987 Effects of birth-related events on central blood flow patterns. Pediatr Res 22:557-566

27. Raj JU, Chen P 1986 Micropuncture measurement of microvascular pressure in isolated lamb lungs during hypoxia. Circ Res 59:398-404

28. Raj JU, Chen P 1986 Microvascular pressures measured by micropuncture in isolated perfused lamb lungs. J Appl Physiol 61:2194-2201

29. Doumas BT, Bayse DD, Carter RJ, Peters Jr T, Schatter R 1981 A candidate reference method for determination of total protein serum. I. Development and validation. Clin Chem 27:1642-1650

30. Jobe A, Jacobs H, Ikegami M, Berry D 1985 Lung protein leaks in ventilated lambs: effect of gestational age. J Appl Physiol 58:1246-125 I

31. Jobe A, Ikegami M, Jacobs H, Jones S, Conaway D 1983 Permeability of premature lamb lungs to protein and the effect of surfactant on that permeability. J Appl Physiol 55:169-176

32. Clyman RI, Campbell D, Heymann MA, Mauray F 1985 Persistent responsiveness of the neonatal ductus arteriosus in immature lambs: a possible cause for reopening of patent ductus arteriosus after indomethacin-induced closure. Circulation 71:141-145

33. Vreim CE, Snashall PD, Demling RH, Staub NC 1976 Lung lymph and free interstitial fluid protein composition in sheep with edema. Am J Physio 230:1650-1653

34. Bressack MA, Bland R 1980 Alveolar hypoxia increases lung fluid filtration in unanesthetized newborn lambs. Circ Res 46:111-116

35. Minnear FL, Barie PS, Malik AB 1981 Lung fluid and protein exchange in the acute sheep preparation. J Appl Physiol 59:1358-1361

36. Hazinski TA, Bland RD, Hansen TN, Sedin EG, Goldberg RB 1986 Effect of hypoproteinemia on lung fluid balance in awake newborn lambs. $\mathrm{J}$ App Physiol 61:1139-1148

37. Younes M, Bshouty Z, Ali J 1987 Longitudinal distribution of pulmonary vascular resistance with very high pulmonary blood flow. J Appl Physiol 62:344-358

38. Rudolph AM, Drorbraugh JE, Auld PAM, Rudolph AJ, Nadas AS, Smith CA Hubbell JP 1961 Studies on the circulation in the neonatal period. The circulation in the respiratory distress syndrome. Pediatrics 27:551-566

39. Fung YC, Yen RT 1986 A new theory of pulmonary blood flow in zone 2 condition. J Appl Physiol 60:1638-1650

40. Berry D, Ikegami M, Jobe A 1989 Lung perfusion and aerosol distributions in preterm ventilated lambs. Pediatr Pulmonol 6:147-152

41. Drake RE, Laine GA 1988 Pulmonary microvascular permeability to fluid and macromolecules. J Appl Physiol 64:487-501

42. Bland RE, Hansen TN, Hazinski TA, Haberkern CM, Bressack MA 1982 Studies of lung fluid balance in newborn lambs. Ann NY Acad Sci 384:126144

43. Bressack MA, McMillan DD, Bland RD 1980 Pulmonary oxygen toxicity: increased microvascular permeability in unanesthetized lambs. Lymphology 12:133-139

44. Taylor AB 1981 Capillary fluid filtration. Starling forces and lymph flow. Circ Res 49:558-575 